\title{
Podziemne magazyny gazu elementem bezpieczeństwa energetycznego Polski
}

\begin{abstract}
W artykule przedstawiono charakterystykę polskich podziemnych magazynów gazu (PMG) i ich rozbudowy, na tle magazynów w krajach członkowskich UE, biorąc pod uwagę okres od wstąpienia Polski do Unii Europejskiej do roku 2015. Możliwość pozyskania funduszy w ramach Programu Operacyjnego Infrastruktura i Środowisko 2007-2013 (działanie 10.1) została przez Polskę w pełni wykorzystana, a efektem podjętych działań było zwiększenie pojemności magazynowej PMG z 1,4 $\mathrm{mld} \mathrm{m}^{3} \mathrm{w}$ roku 2005 do około $2,9 \mathrm{mld} \mathrm{m}^{3} \mathrm{w}$ roku 2015. Zrealizowano wówczas cztery przedsięwzięcia związane z budową/rozbudową podziemnych magazynów gazu: Wierzchowice, Strachocina, Kosakowo, Husów, o łącznej wartości około $2745 \mathrm{mln}$ zł, przy dofinansowaniu z UE na poziomie $704 \mathrm{mln}$ zł. Obecnie powtórnie istnieje możliwość dofinansowania rozbudowy PMG w ramach tzw. II perspektywy (2014-2020). Na zagadnienie to należy spojrzeć kompleksowo, biorąc pod uwagę cały system przesyłowy gazu, w aspekcie zapewnienia bezpieczeństwa energetycznego kraju. PMG stanowią ważny element tego systemu.
\end{abstract}

Słowa kluczowe: bezpieczeństwo energetyczne, podziemny magazyn gazu, pojemność czynna magazynu, system przesyłowy gazu ziemnego.

\section{Underground gas storage facilities - an element of Polish energy security}

The article presents characteristic qualities of Polish underground gas storage (USG) and their expansion as compared to USG in EU member states, taking into account the period from Poland s accession to the European Union to 2015. The possibility of obtaining funds from the Operational Programme for Infrastructure and Environment 2007-2013 (Activity 10.1) was fully used by Poland, and as a result, the storage capacity of USG increased from $1.4 \mathrm{bn} \mathrm{m}^{3}$ in 2005 to approximately $2.9 \mathrm{bn} \mathrm{m}^{3}$ in 2015 . Four projects were completed, in connection with the construction/ expansion of underground gas storage in: Wierzchowice, Strachocina, Kosakowo, Husów, at a total cost of about PLN 2.745 bn, with EU subsidies of PLN 0.704 bn. Currently, another possibility has arisen for obtaining subsidies for the expansion of UGS, as part of the new prospect (2014-2020). This issue must be examined comprehensively, taking into consideration the entire gas transmission system, in the aspect of ensuring Poland's energy security. USG are a vital component of this system.

Key words: energy security, underground gas storage, storage working capacity, natural gas transmission system.

\section{Wstęp}

Analiza systemu magazynowania gazu (PMG) w Polsce na tle dotychczasowych kierunków inwestycyjnych w tym zakresie w krajach Unii Europejskiej wskazuje na konieczność dalszego intensywnego rozwoju tego systemu, ściśle związanego z użytkowaniem gazu jako nośnika energii.

Dalszy rozwój powinien uwzględniać m.in.:

- optymalizację lokalizacji PMG - z wzięciem pod uwagę m.in. przepustowości systemu przesyłowego oraz nowych kierunków dostaw gazu,

- nowe koncepcje w typowaniu litostratygraficznych pułapek dla budowy PMG (np. w sczerpanych wielohoryzontalnych czy masywowych złożach gazu ziemnego), ale także szerokie plany branży gazowniczej dotyczące pełnienia przez PMG coraz to nowszych funkcji, związanych 


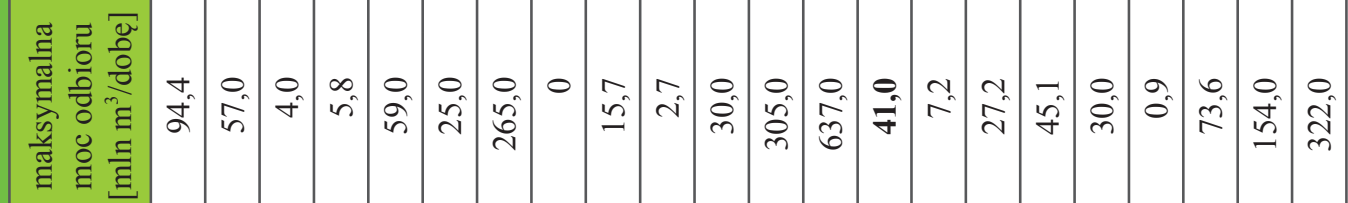

กับ

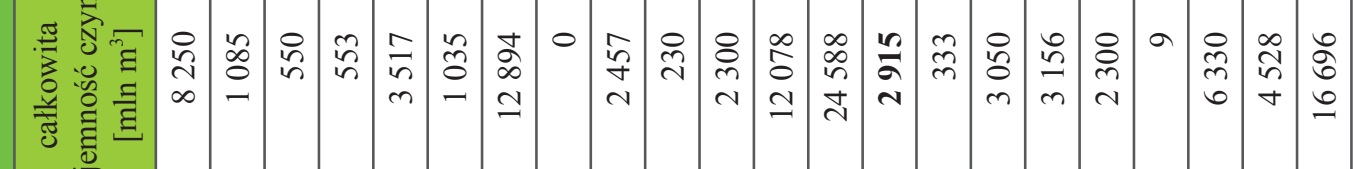

$\stackrel{n}{\stackrel{2}{2}}$

$\stackrel{\circ}{\circ}$

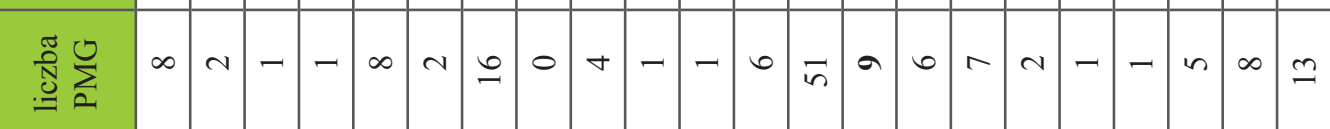

岂

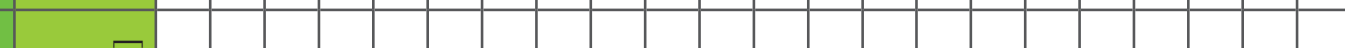

$\frac{\ddot{0}}{\frac{\pi}{5}}$

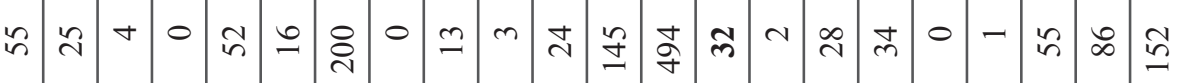

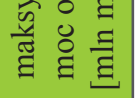

药

苞

3

$\sum_{0}^{0}$

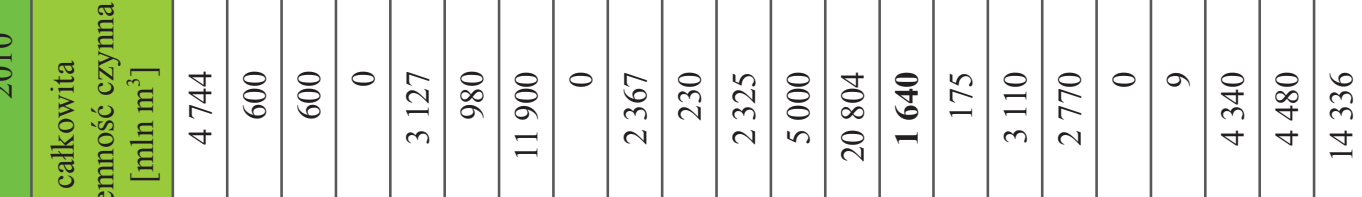

$\sum_{=}$

可

.

胥

공

늄

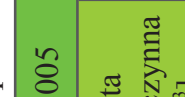

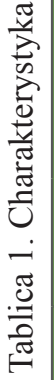

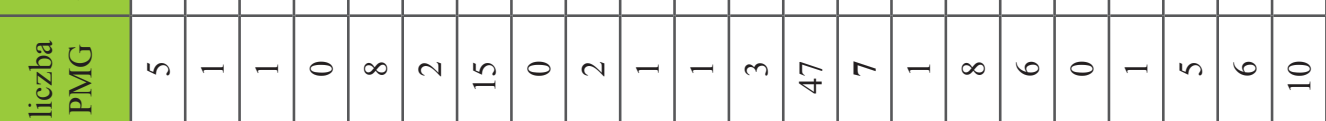

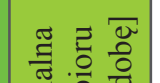

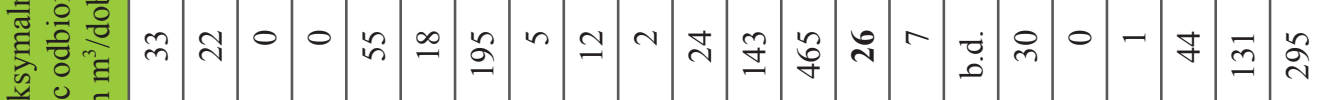

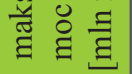

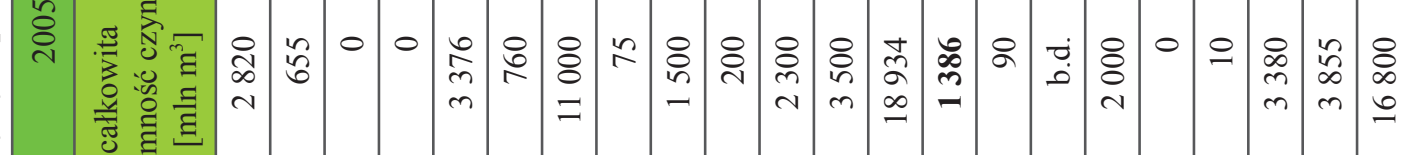

$\frac{2}{2}$

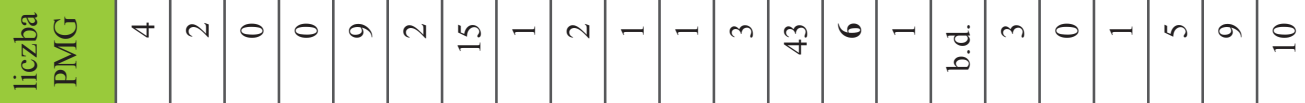

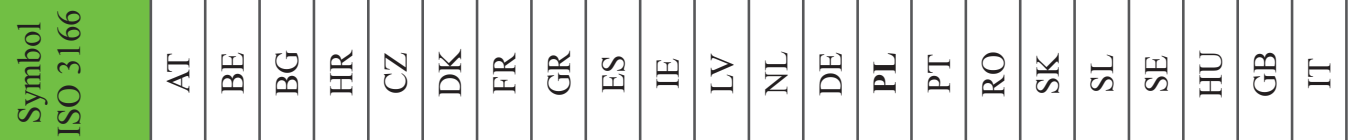

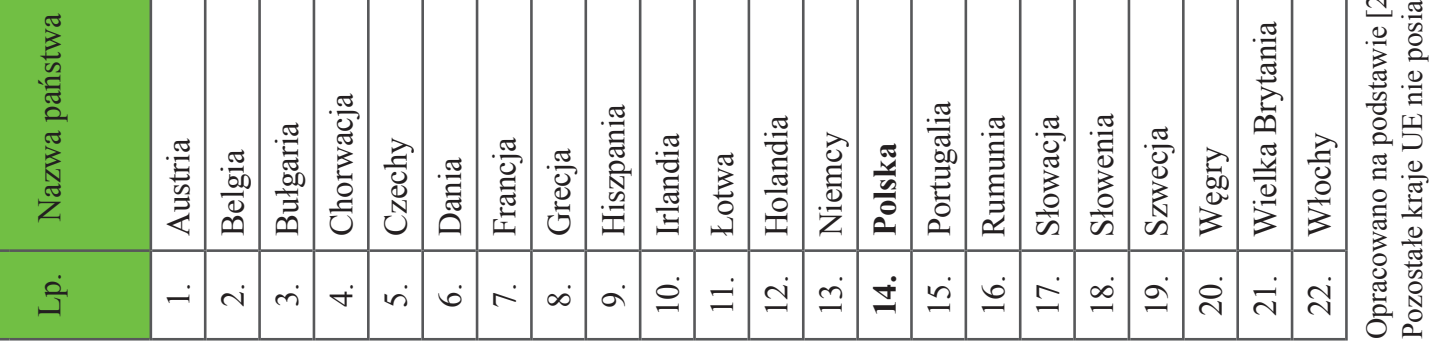

$\sum_{a}^{0}$

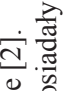
$\frac{10}{3} \stackrel{0}{0}$ 要 陼 닌 䨔 范 
np. z planowanym utworzeniem w Polsce hubu gazowego dla Europy Środkowo-Wschodniej. Tego typu działania wymagają m.in. zabezpieczenia ciągłości pracy takiego hubu, z uwagi na obroty zdecydowanie większymi już ilościami gazu ziemnego, a co się z tym wiąże - zaprojektowania także nowego rodzaju usługi magazynowania.

Kilkudziesięcioletnie krajowe doświadczenie w budowie PMG jest ogromnym atutem przy projektowaniu strategii rozwoju systemu magazynowania gazu, stanowiącego nieodzowny element bezpieczeństwa energetycznego, bezpośrednio związanego z utrzymaniem stałych dostaw gazu do odbiorców, niezależnie od uwarunkowań technicznych, klimatycznych czy politycznych.

I chociaż otwarcie gazoportu w Świnoujściu, a także dalsze rządowe plany budowy połączenia Polski ze złożami norweskimi całkowicie dywersyfikują kierunki dostaw gazu, to posiadanie odpowiednich pojemności magazynowych dla gazu jest nadal priorytetowym zadaniem.

\section{Charakterystyka wybranych parametrów podziemnych magazynów gazu w krajach UE w latach 2005-2015}

Budowa i rozbudowa podziemnych magazynów gazu (PMG), umożliwiających prawidłowe funkcjonowanie systemu gazowego, a także optymalizację sterowania pracą tego systemu, związana jest przede wszystkim:

- z priorytetami w polityce energetycznej danego kraju, w której niezależność w decydowaniu o kierunkach, jak i warunkach dostaw gazu nabiera pierwszoplanowego znaczenia,

- z wielkością zużycia gazu przez odbiorców, jak i rozmiarem istniejącego systemu przesyłowego i dystrybucyjnego, pokrywającego w różnym stopniu powierzchnię danego kraju,

- z zasobnością ekonomiczną kraju i jego mieszkańców.

W poszczególnych zestawieniach tabelarycznych przedstawiono informacje odnoszące się do PMG w państwach Unii Europejskiej.

- W tablicy 1 zamieszczono charakterystykę wybranych parametrów PMG w krajach UE w latach 2005, 2010, 2015, biorąc pod uwagę fakt przyjęcia Polski do UE w 2004 roku.

- W tablicy 2 zawarto łączną liczbę PMG w krajach UE i ich parametry w latach 2005, 2010, 2015. Obserwuje się w tym okresie przyrost 33 magazynów w stosunku do roku 2005

Tablica 2. Łączna liczba PMG w krajach UE oraz ich charakterystyka w poszczególnych latach: 2005, 2010, 2015

\begin{tabular}{|c|c|c|c|c|}
\hline Lp. & $\begin{array}{c}\text { Rok } \\
\text { Liczba krajów } \\
\text { UE }\end{array}$ & $\begin{array}{c}\text { Liczba } \\
\text { PMG }\end{array}$ & $\begin{array}{c}\text { Całkowita } \\
\text { pojemność } \\
\text { czynna PMG } \\
{\left[\mathrm{mln} \mathrm{m}^{3}\right]}\end{array}$ & $\begin{array}{c}\text { Maksymalna } \\
\text { moc odbioru } \\
\text { gazu } \\
{\left[\mathrm{mln} \mathrm{m}^{3} /\right.} \\
\text { dobę }]\end{array}$ \\
\hline 1. & 2005 (UE 25) & 120 & 69940 & 1481 \\
\hline 2. & 2010 (UE 27) & 130 & 83537 & 1421 \\
\hline 3. & 2015 (UE 28) & 153 & 108755 & 1996 \\
\hline
\end{tabular}

Opracowano na podstawie [2]. oraz wzrost pojemności czynnej PMG o $38815 \mathrm{mln} \mathrm{m}^{3}$ i mocy zatłaczania gazu o $515 \mathrm{mln} \mathrm{m}^{3} /$ dobę.

- Tablica 3 daje odpowiedź na pytanie, w jakim procencie PMG stanowią zabezpieczenie funkcjonowania systemu gazowego w poszczególnych krajach. Polska w tym zestawieniu znajduje się na 11 pozycji pod względem wielkości pojemności czynnej PMG. Pierwsze cztery miejsca zajmują starzy członkowie Unii Europejskiej, z niemieckim liderem (24 $588 \mathrm{mln} \mathrm{m}^{3}$ ). Średni stopień pokrycia zapotrzebowania gazu w pojemności czynnej PMG wynosi $32 \%$ ( $18,2 \%$ dla Polski).

- Tablica 4 pt. Zużycie energii pierwotnej przypadajace na 1 mieszkańca w krajach UE (dane z roku 2014) wskazuje, że Polska znajduje się na odległej, 18. pozycji. W tym zakresie nasz kraj ma jeszcze dużo do zrobienia.

- Tablica 5 pt. Dlugości sieci gazowej (przesyłowej i dystrybucyjnej) w wybranych krajach Unii Europejskiej informuje, że Polska w tym zestawieniu plasuje się na 5 pozycji, po Niemczech, Włoszech, Wielkiej Brytanii i Francji, osiągając przyrost długości sieci w stosunku do roku 2005 na poziomie $63,3 \%$. Jest to bezwzględne osiągnięcie naszego przemysłu, wsparte w ostatnich latach środkami unijnymi.

Kraje posiadające PMG o największej łącznej mocy zatłaczania gazu to:

1. Niemcy

2. Włochy

$-637 \mathrm{mln}^{3} /$ dobę,

3. Holandia

$-322 \mathrm{mln} \mathrm{m}^{3} /$ dobę,

4. Francja

$-305 \mathrm{mln} \mathrm{m}^{3} /$ dobę,

$-265 \mathrm{mln} \mathrm{m}^{3} /$ dobę

5. Wielka Brytania $-154 \mathrm{mln} \mathrm{m}^{3} /$ dobę.

Dla porównania polskie PMG charakteryzują się mocą na poziomie $41 \mathrm{mln} \mathrm{m}^{3} /$ dobę. 
Tablica 3. Stopień pokrycia rocznego zapotrzebowania gazu ziemnego poprzez PMG w wybranych krajach UE

\begin{tabular}{|c|l|c|c|c|}
\hline Lp. & Nazwa kraju & $\begin{array}{c}\text { Całkowita pojemność } \\
\text { czynna PMG } \\
{\left[\mathrm{mln} \mathrm{m}^{3}\right]}\end{array}$ & $\begin{array}{c}\text { Roczne zużycie } \\
\text { gazu ziemnego } \\
{\left[\mathrm{mld} \mathrm{m}^{3}\right]}\end{array}$ & $\begin{array}{c}\text { Stopień pokrycia } \\
(\text { kol. 3/kol. 4) } 100 \\
W[\%]\end{array}$ \\
\hline 1. & Niemcy & 24588 & 76,4 & 32,2 \\
\hline 2. & Włochy & 16696 & 60,7 & 27,5 \\
\hline 3. & Francja & 12894 & 38,6 & 33,4 \\
\hline 4. & Holandia & 12078 & 34,5 & 35,0 \\
\hline 5. & Austria & 8250 & 7,7 & 107,1 \\
\hline 6. & Węgry & 6330 & 8,5 & 74,5 \\
\hline 7. & W. Brytania & 4528 & 71,5 & 6,3 \\
\hline 8. & Czechy & 3517 & 7,2 & 73,8 \\
\hline 9. & Słowacja & 3156 & 4,3 & 27,7 \\
\hline 10. & Rumunia & 3050 & 11,0 & $\mathbf{1 8 , 2}$ \\
\hline 11. & Polska & $\mathbf{2 9 1 5}$ & $\mathbf{1 6 , 0}$ & \\
\hline
\end{tabular}

Objaśnienia: dane dotyczące rocznego zużycia gazu z 2014 r. [2].

Tablica 4. Zużycie energii pierwotnej przypadające na 1 mieszkańca w krajach UE (dane $\mathrm{z}$ roku 2014)

\begin{tabular}{|l|c|l|c|}
\hline \multicolumn{3}{|c|}{ Kraje, w których zużycie energii pierwotnej ${ }^{1} Z\left[\right.$ toe] $^{2}$} \\
\hline \multicolumn{2}{|c|}{$\begin{array}{c}\text { przewyższa wartość średnią } \\
\text { dla UE 28 }\end{array}$ Nazwa kraju } & $Z$ toe & \multicolumn{2}{c|}{ jest mniejsze od średniej dla UE 28 } \\
\hline Luksemburg & 7,64 & Nazwa kraju & $Z$ [toe] \\
\hline Finlandia & 5,87 & Wielka Brytania & 2,94 \\
\hline Szwecja & 5,23 & Irlandia & 2,90 \\
\hline Belgia & 4,82 & Włochy & 2,88 \\
\hline Estonia & 4,49 & Hiszpania & 2,74 \\
\hline Holandia & 4,31 & Polska & 2,55 \\
\hline Niemcy & 3,88 & Litwa & $\mathbf{2 , 5 0}$ \\
\hline Austria & 3,88 & Węgry & 2,39 \\
\hline Czechy & 3,83 & Bułgaria & 2,37 \\
\hline Francja & 3,79 & Lotwa & 2,33 \\
\hline Słowenia & 3,25 & Grecja & 2,18 \\
\hline Dania & 3,19 & Cypr & 2,14 \\
\hline \multirow{2}{*yyy}{} & & Portugalia & 2,10 \\
\cline { 3 - 5 } & & Chorwacja & 2,03 \\
\cline { 3 - 5 } & & Malta & 1,88 \\
\cline { 3 - 5 } & & Rumunia & 1,69 \\
\hline
\end{tabular}

Dla porównania z krajami spoza UE, np.:

- USA $Z=6,92$ toe;

- Japonia $Z=3,47$ toe;

- Szwajcaria

- Turcja
$Z=3,25$ toe; $Z=1,25$ toe.

Opracowano na podstawie [5].

Objaśnienia:

${ }^{1}$ Źródła energii - ropa naftowa, gaz ziemny, paliwa kopalne stałe, energia jądrowa, hydroenergia i in

${ }^{2}$ toe - jednostka paliwa umownego; energetyczny równoważnik 1 tony ropy naftowej o wartości opałowej 10 tys. $\mathrm{kcal} / \mathrm{kg}$.

1 toe $=\sim 42 \mathrm{GJ}$ lub $\sim 11,6 \mathrm{MWh}$ 
Tablica 5. Długości sieci gazowej (przesyłowej i dystrybucyjnej) w wybranych krajach Unii Europejskiej [km]

\begin{tabular}{|c|c|c|c|}
\hline Kraj $\quad$ Rok & 2005 & 2014 & $\Delta[\%]$ \\
\hline Austria & 32765 & 46000 & 40,4 \\
\hline Belgia & 59300 & 74795 & 26,1 \\
\hline Czechy & 72837 & 76910 & 5,6 \\
\hline Niemcy & 380000 & 505000 & 32,9 \\
\hline Hiszpania & 52122 & 81807 & 57,0 \\
\hline Francja & 217773 & 232094 & 6,6 \\
\hline Grecja & 3896 & 7392 & 89,7 \\
\hline Węgry & 84320 & 89040 & 5,6 \\
\hline Włochy & 232190 & 291038 & 25,3 \\
\hline Litwa & 8000 & 10507 & 31,3 \\
\hline Łotwa & 5150 & 6206 & 20,5 \\
\hline Portugalia & 11707 & 18502 & 58,0 \\
\hline Polska & 116349 & 189949 & 63,3 \\
\hline Słowacja & 32802 & 35595 & 8,5 \\
\hline Wielka Brytania & 281477 & 285600 & 1,5 \\
\hline$\Sigma \mathrm{UE}$ & $\begin{array}{c}1769070 \\
\text { (UE 24) }\end{array}$ & $\begin{array}{c}2214471 \\
\text { (UE 28) }\end{array}$ & 25,2 \\
\hline
\end{tabular}

Kraje UE posiadające największe długości sieci gazowych (dane z roku 2014):
1. Niemcy
$505000 \mathrm{~km}$,
2. Włochy
$291038 \mathrm{~km}$,
3. Wielka Brytania
$295600 \mathrm{~km}$,
4. Francja
$232094 \mathrm{~km}$,
5. Polska
$189949 \mathrm{~km}$.

Opracowano na podstawie danych [2].

Objaśnienia:

$\Delta$ - Przyrost długości sieci w roku 2014 w odniesieniu do stanu z roku 2005 [2].

\section{Podziemne magazyny gazu ziemnego w Polsce}

\section{Budowa nowych i rozbudowa istniejących PMG w ramach projektów zrealizowanych przez PGNiG SA, a dofinansowanych ze środków unijnych}

Fundusze unijne przyznane Polsce po wejściu do UE, w tzw. I perspektywie finansowej 2007-2013, były dystrybuowane poprzez Program Operacyjny Infrastruktura i Środowisko (POIiŚ), w ramach działania 10.1 priorytetu X, pn. Bezpieczeństwo energetyczne, w tym dywersyfikacja źródet energii.

W działaniu 10.1, pn. Rozwój systemów przesyłowych energii elektrycznej gazu ziemnego i ropy naftowej oraz budowa i rozbudowa podziemnych magazynów gazu ziemnego, PGNiG SA zrealizowało cztery przedsięwzięcia:

1) Podziemny Magazyn Gazu „Wierzchowice”;

2) Podziemny Magazyn Gazu „Strachocina”;

3) Kawernowy Podziemny Magazyn Gazu „Kosakowo”;

4) Podziemny Magazyn Gazu „Husów”.

Łączna wartość tych projektów wyniosła $2746,73 \mathrm{mln}$ zł, $\mathrm{z}$ czego dofinansowanie $\mathrm{z}$ funduszy unijnych kształtowało się na poziomie $25,63 \%$, co stanowiło kwotę 704,12 mln zł. Efektem tych projektów było zwiększenie pojemności czyn-

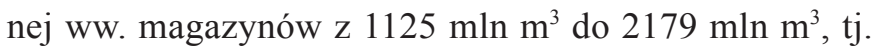
o 94\% pojemności wyjściowej.
W tablicy 6 przedstawiono charakterystykę tych przedsięwzięć.

\section{Moce instalacji magazynowych na sezon 2016/2017}

Aktualnie w kraju eksploatowanych jest 7 podziemnych magazynów gazu ziemnego wysokometanowego, współpracujących z systemem przesyłowym.

Na podstawie danych należącego do PGNiG SA Operatora Systemu Magazynowania (OSM) [6], eksploatującego podziemne magazyny gazu wysokometanowego, maksymalne zdolności instalacji magazynowych w sezonie 2016/2017 przedstawiono $\mathrm{w}$ tablicy 7 .

Pojemności czynne PMG w latach ubiegłych [8] kształtowały się następująco:

- sezon 2012/2013 - 1821,89 $\mathrm{mln} \mathrm{m}^{3}$;

- $\quad$ sezon $2013 / 2014-1817,89 \mathrm{mln} \mathrm{m}^{3}$;

- sezon 2014/2015 - 2524,09 $\mathrm{mln} \mathrm{m}^{3}$;

- sezon 2015/2016-2795,60 mln $\mathrm{m}^{3}$.

Zestawienie pojemności czynnych PMG od roku 2012 wskazuje na ich istotny wzrost. Był on związany z realizacją przez PGNiG SA czterech projektów dotyczących rozbudowy podziemnych magazynów gazu, dofinansowanych ze środków unijnych. 
Tablica 6. Podziemne magazyny gazu PGNiG SA zmodernizowane/wybudowane przy udziale środków unijnych

\begin{tabular}{|c|c|c|c|c|c|}
\hline \multirow{2}{*}{ Lp. } & \multirow{2}{*}{ Okres realizacji projektu } & \multirow{2}{*}{$\begin{array}{l}\text { Wartość projektu } \\
\quad[\mathrm{mln} \mathrm{zl}]\end{array}$} & \multirow{2}{*}{$\begin{array}{l}\text { Dofinansowanie UE } \\
\qquad[\mathrm{mln} \mathrm{zl}]\end{array}$} & \multicolumn{2}{|c|}{$\begin{array}{l}\text { Pojemność czynna } \\
\text { magazynu }\end{array}$} \\
\hline & & & & $\begin{array}{l}\text { przed rozbudową } \\
\quad\left[\mathrm{mln} \mathrm{m}^{3}\right]\end{array}$ & $\begin{array}{l}\text { po rozbudowie } \\
{\left[\mathrm{mln} \mathrm{m}^{3}\right]}\end{array}$ \\
\hline \multicolumn{6}{|c|}{ Podziemny Magazyn Gazu „Wierzchowice” } \\
\hline 1. & $16.05 .2007-31.03 .2015$ & 1743,03 & 484,56 & 575 & 1200 \\
\hline \multicolumn{6}{|c|}{$\begin{array}{l}\text { Zrealizowano dwa główne zadania: } \\
\text { Zadanie 1. Budowa części napowierzchniowej magazynu, m.in. } 2 \text { jednostek turbokompresorów oraz } 1 \text { turbiny do pracy ciągłej, } \\
\text { układu odzysku ciepła z gazów odlotowych turbiny gazowej, urządzeń i przyłączy elektrycznych, turboekspandera wraz z generato- } \\
\text { rem prądu, instalacji osuszania gazu, centralnej sterowni do prowadzenia i kontroli procesów technologicznych w PMG, stacji roz- } \\
\text { działu gazu. } \\
\text { Zadanie 2. Wykonanie w części podziemnej magazynu } 3 \text { odwiertów horyzontalnych i rekonstrukcji } 1 \text { otworu. }\end{array}$} \\
\hline \multicolumn{6}{|c|}{ Podziemny Magazyn Gazu „Strachocina” } \\
\hline 2. & $16.05 .2007-30.06 .2012$ & 412,90 & 69,72 & 150 & 360 \\
\hline \multicolumn{6}{|c|}{$\begin{array}{l}\text { Zadanie 1. Budowa części napowierzchniowej magazynu, m.in. ośrodka centralnego wraz ze stacją filtrów gazu, stacjami: pomia- } \\
\text { rową, rozdziału i osuszania gazu oraz tłoczni gazu, ośrodków grupowych I i II, nowych gazociągów, systemów bezpieczeństwa - } \\
\text { wgłębnych i napowierzchniowych. } \\
\text { Zadanie 2. Wykonanie w części podziemnej } 8 \text { odwiertów kierunkowych. }\end{array}$} \\
\hline \multicolumn{6}{|c|}{ Kawernowy Magazyn Gazu „Kosakowo” } \\
\hline 3. & $26.06 .2007-31.03 .2015$ & 514,12 & 114,69 & 0 & 119 \\
\hline \multicolumn{6}{|c|}{$\begin{array}{l}\text { Zadanie 1. jw. } \\
\text { Zadanie 2. Budowa instalacji ługowniczej wraz z rurociągiem do zrzutu solanki oraz wykonanie } 4 \text { kawern magazynowych. }\end{array}$} \\
\hline \multicolumn{6}{|c|}{ Podziemny Magazyn Gazu „Husów” } \\
\hline 4. & $12.04 .2012-31.05 .2015$ & 76,68 & 35,15 & 400 & 500 \\
\hline $\begin{array}{l}\text { Zakul } \\
\text { nicę } 8 \\
\text { mane }\end{array}$ & $\begin{array}{l}\text { sprężarkę oraz wybudow } \\
\text { tację filtroseparatorów, z } \\
\text { e i technologiczne, przeb }\end{array}$ & $\begin{array}{l}\text { części napowierzc } \\
\text { kondensatu, rozd } \\
\text { ho sieci m.in.: gazc }\end{array}$ & $\begin{array}{l}\text { ej m.in. budynek sta } \\
\text { elektryczną, estaka } \\
\text { w, elektroenergetyc }\end{array}$ & $\begin{array}{l}\text { acy obudowę agr } \\
\text { d instalację, drog } \\
\text { analizacyjne, grz }\end{array}$ & $\begin{array}{l}\text { sprężarki, chłod } \\
\text { vnętrzne, place } \\
\text { e, teletechniczne }\end{array}$ \\
\hline
\end{tabular}

Opracowano na podstawie materiałów INiG - PIB.

Tablica 7. Maksymalne zdolności instalacji magazynowych w sezonie 2016/2017

\begin{tabular}{|c|c|c|c|c|c|c|c|}
\hline \multirow{2}{*}{$\begin{array}{c}\text { Grupa } \\
\text { instalacji } \\
\text { magazynowych }\end{array}$} & \multirow{2}{*}{$\begin{array}{c}\text { Magazyn gazu } \\
\text { wysokometanowego }\end{array}$} & \multicolumn{2}{|c|}{ Pojemność czynna } & \multicolumn{2}{|c|}{$\begin{array}{c}\text { Maksymalna moc } \\
\text { zatłaczania }\end{array}$} & \multicolumn{2}{|c|}{$\begin{array}{l}\text { Maksymalna moc } \\
\text { odbioru }\end{array}$} \\
\hline & & $\mathrm{mln} \mathrm{m}^{3}$ & GWh & $\mathrm{mln} \mathrm{m}^{3} /$ dobę & GWh/dobę & $\mathrm{mln} \mathrm{m}^{3} /$ dobę & GWh/dobę \\
\hline \multirow{2}{*}{ GIM Kawerna } & KPMG Mogilno & 594,65 & 6624,4 & 9,60 & 106,9 & 18,0 & 200,5 \\
\hline & KPMG Kosakowo & 119,00 & 1326,9 & 2,40 & 26,8 & 9,60 & 107,0 \\
\hline \multirow{4}{*}{ GIM Sanok } & PMG Husów & 500,00 & 5625,0 & 4,15 & 46,7 & 5,76 & 64,6 \\
\hline & PMG Strachocina & 360,00 & 4050,0 & 2,64 & 29,7 & 3,36 & 37,9 \\
\hline & PMG Swarzów & 90,00 & 1008,0 & 1,00 & 11,2 & 1,00 & 11,2 \\
\hline & PMG Brzeźnica & 65,00 & 731,3 & 1,10 & 12,4 & 0,93 & 10,4 \\
\hline- & PMG Wierzchowice & 1200,00 & 13200,0 & 6,00 & 66,0 & 9,60 & 105,6 \\
\hline \multicolumn{2}{|r|}{ Suma } & 2928,65 & 32565,5 & 26,89 & 299,7 & 48,25 & 537,2 \\
\hline
\end{tabular}

\section{Możliwości i potrzeby dalszej rozbudowy PMG}

Obecnie Instytut Nafty i Gazu - PIB pełni rolę instytucji wdrażającej Program Operacyjny Infrastruktura i Środowi- sko 2014-2020 dla działania 7.1 pn. Rozwój inteligentnych systemów magazynowania, przesylu i dystrybucji energii, 
w ramach którego dofinansowywane będą ze środków unijnych projekty związane m.in. z budowa i/lub przebudowa magazynów gazu ziemnego.

II perspektywa finansowa UE ujmuje w zakresie gazownictwa także dalszą budowę i/lub przebudowę sieci przesyłowych i dystrybucyjnych gazu ziemnego czy zwiększenie możliwości regazyfikacji terminalu LNG w Świnoujściu. Ale program rozwoju PMG stanowi nieodzowny element całego systemu przesyłowego gazu ziemnego i tylko w takim kontekście można rozpatrywać to zagadnienie.

Ostateczne decyzje co do dalszej budowy/rozbudowy PMG nie zostały jeszcze podjęte przez PGNiG, dotychczas jedynego właściciela i dysponenta tych magazynów. Sytuacja ta wynika z konieczności uwzględnienia wiążących wyborów i rozstrzygnięć w skali całego kraju, a dotyczących kompleksowego programu rządowego, związanego z bezpieczeństwem energetycznym Polski. Rozstrzygnięcia te będą podejmowane m.in. odnośnie do budowy/rozbudowy:

- strategicznego połączenia systemu gazowego Polski z norweskim szelfem, m.in. poprzez budowę odnogi gazociągu z Danii (tzw. Baltic Pipe), dywersyfikującego zarówno źródła, jak i kierunki dostaw gazu do Polski,

- konektorów łączących system przesyłowy Polski m.in. z Litwą, Czechami, Słowacją, Ukrainą i Niemcami,

- polskiego hubu gazowego, będącego platformą obrotu paliwem gazowym, zapewniającą płynność i niezawodność transakcji,

- terminalu LNG poprzez zwiększenie zdolności regazyfikacji LNG do 7,5 $\div 10 \mathrm{mld} \mathrm{m}^{3}$.

W strategii GAZ-SYSTEM S.A. oprócz ww. planów znajdują się zadania priorytetowe, jak:

- rozbudowa systemu przesyłowego o $2000 \mathrm{~km}$ nowoczesnych gazociągów do roku 2025, w dwóch wariantach:

- w Polsce północno-zachodniej (wariant podstawowy),

- w kierunku południowo-wschodnim, z umożliwieniem eksportu gazu na Ukrainę (wariant alternatywny).

W wariancie alternatywnym rozważany jest projekt ulokowania w Zatoce Gdańskiej pływającej jednostki będącej terminalem LNG (do $10 \mathrm{mld} \mathrm{m}^{3}$ ) - w przypadku, gdyby połączenie z norweskim szelfem nie doszło do skutku $[4,9]$.

Polska Spółka Gazownicza w swym pakiecie zmian strategicznych do roku 2023 zamierza zwiększyć stopień gazyfikacji kraju poprzez zgazyfikowanie 74 nowych gmin, co oznacza w praktyce powstanie około 350 tys. nowych przyłączy [5].

PGNiG przygotowuje program wsparcia zmian w otoczeniu regulacyjnym, zmierzającym do poprawy rentowności w zakresie magazynowania gazu [7].
Tak więc dopiero kompleksowe spojrzenie na cel podstawowy, jakim jest zapewnienie bezpieczeństwa energetycznego i wynikające z niego priorytety, pozwoli na zdefiniowanie potrzeb w zakresie rozbudowy pojemności PMG. Takie możliwości istnieją, zarówno poprzez rozbudowę istniejącej infrastruktury magazynowej, jak i budowę nowej. W kraju dostępne są odpowiednie struktury geologiczne do tego celu, a także doświadczona kadra, zarówno do projektowania PMG, jak i ich budowy.

Odpowiednio stworzona w kraju sieć PMG o najwyższych standardach powinna zapewnić podstawowe funkcje, związane m.in. z utrzymaniem rezerwy strategicznej, równoważenie sezonowej zmienności zapotrzebowania na gaz czy optymalizowanie systemu przesyłowego w aspekcie oceny wielkości importu gazu [3, 8].

Obecna pojemność PMG wynosi około 2,9 $\mathrm{mld}^{3}$. Trwają jeszcze dyskusje w gronie specjalistów, jaką pojemnością magazynową powinien dysponować system krajowy w niedalekiej i trochę dalszej perspektywie. Należałoby popatrzeć na wskaźnik odzwierciedlający stosunek pojemności PMG do rocznego zapotrzebowania na gaz w innych krajach - $W[\%]$ (tablica 3).

I tak dla Niemiec wskaźnik $W$ wynosi $32,2 \%$, dla Francji $-W=33,4 \%$, dla Holandii $-W=35,0 \%$, dla Włoch $W=27,5 \%$, natomiast dla Polski $-W=18,2 \%$.

Można zatem założyć, że wykorzystując doświadczenia innych krajów, należałoby docelowo dążyć do zwiększenia wskaźnika $W$ dla Polski do poziomu około $30 \%$, tzn. do pojemności PMG około 4,8 $\mathrm{mld} \mathrm{m}^{3}$.

Natomiast biorąc pod uwagę program rządowy w zakresie bezpieczeństwa energetycznego kraju, a także ambicje, by Polska stała się liderem i przejęła funkcję istotnego gracza na rynku gazowym w Europie Środkowej i nie tylko - wskazana powyżej pojemność docelowa PMG z pewnością nie będzie wystarczająca.

Najpierw jednak spróbujmy osiągnąć pierwszą wartość docelową, a będzie to olbrzymi sukces.

Należy także zwrócić uwagę na konieczność włączenia w proces szeroko pojętej rozbudowy PMG jednostek naukowych, dysponujących rozwiązaniami o znaczącym potencjale rozwojowym w całym łańcuchu węglowodorowym, od poszukiwania odpowiednich struktur do podziemnego magazynowania gazu, poprzez technologie wiercenia otworów w aspekcie PMG, aż po konstrukcje statycznych i dynamicznych symulacyjnych modeli PMG do prognozowania pracy magazynów i analizy przebiegu procesów zachodzących przy sczerpywaniu zasobów / zatłaczaniu gazu, przy wykorzystaniu zaawansowanych metod matematycznych [1]. 


\section{Podsumowanie}

W chwili obecnej podejmowane są rządowe decyzje dotyczące ostatecznych rozstrzygnięć w zakresie polityki energetycznej Polski w perspektywie krótko-, średnio- i długookresowej. Decyzje te ukierunkowane są m.in. na zapewnienie niezależności energetycznej kraju, poprzez dywersyfikację kierunków i źródeł dostaw gazu ziemnego, na rozbudo- wę i modernizację infrastruktury wydobywczej, przesyłowej i magazynowej gazu, a także na rozwój innowacyjności technologii energetycznych i ich wdrożenie w przemyśle.

Zwiększenie pojemności PMG stanowi zatem jeden $\mathrm{z}$ istotnych elementów polityki energetycznej, a środki unijne uzyskane na ten cel mogą wspomóc i przyspieszyć jego realizację.

Prosimy cytować jako: Nafta-Gaz 2016, nr 10, s. 833-840, DOI: 10.18668/NG.2016.10.08

Artykuł nadesłano do Redakcji 10.08.2016 r. Zatwierdzono do druku 3.10.2016 r.

\section{Literatura}

[1] Ciechanowska M.: Kierunki działalności naukowo-badawczej INiG - PIB w perspektywie krótko- $i$ średniookresowej. Nafta-Gaz 2014, nr 12, s. 974-978.

[2] Eurogas Statistical Reports 2005, 2006, 2010, 2015; http:// www.eurogas.org/uploads/2016/flipbook/statistical-report (dostęp: 02.07.2016).

[3] European Commission: The role of gas storage in internal market and in ensuring security of supply. 2015; https://ec.europa.eu/energy/sites/ener/files/documents/REPORT-Gas Storage-20150728.pdf (dostęp: 09.07.2016).

[4] GAZ-SYSTEM: Plan rozwoju w zakresie zaspokojenia obecnego i przyszłego zapotrzebowania na paliwa gazowe na lata 2014-2023. Wyciag. http://www.gaz-system.pl/fileadmin/ pics_pl/Inwestycje/Plan_Rozwoju_GAZ_SYSTEM_S.A. na lata 2014-2023.pdf (dostęp: 02.07.2016).

[5] Łatanik R.: Pakiet zmian strategicznych wypracowaliśmy wspólnie. Przegląd Gazowniczy 2016, vol. 50, nr 2, s. 32-33.

[6] Mapa lokalizacji - podziemne magazyny gazu w Polsce. Strona internetowa Operatora Systemu Magazynowania; http://www. osm.pgnig.pl/pl/magazyny (dostęp: 16.07.2016).
[7] PGNiG SA: Strategia GK PGNiG na lata 2014-2022. Aktualizacja. Kwiecień 2016; http://www.pgnig.pl/pgnig/o-nas/ strategia (dostęp: 02.07.2016).

[8] Polit J., Mazurowski M., Gałek G.: Uwarunkowania strategii rozwoju podziemnych magazynów gazu ziemnego w Polsce. Nafta-Gaz 2010, nr 10, s. 892-897.

[9] Stępień T.: Strategia GAZ-SYSTEM na następne dziesięciolecia. Przegląd Gazowniczy 2016, vol. 50, nr 2, s. 36-37.

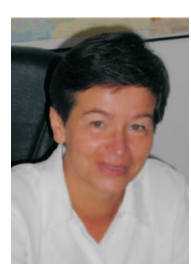

Prof. nzw. dr hab. inż. Maria CIECHANOWSKA Dyrektor Naczelny Instytutu Nafty i Gazu Państwowego Instytutu Badawczego ul. Lubicz 25 A 31-503 Kraków E-mail: maria.ciechanowska@inig.pl 